\title{
農村主婦の生活意識·生活様式と家事の外部化ニーズ 一農協の生活購買事業に関連して一
}

石田正昭

\section{1.はじめに}

家計消費の高度化・サービス化が進行するなかで，

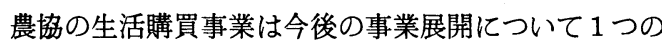
岐路に立たされている．その岐路とは，乙れまでの食 料品・日用雑貨品など生活必需品を中心とした「単な る食品スーパー」の形態にとどまるか，あるいはまた 単なる食品スーパーから脱皮して、小売業とサービス 業を結合したかたちの「暮らしのための総合センタ 一」へ変身するかという問題である。乙の問題を組織 論的にとらえれば，農協は職能組合か地域組合かとい う古くて新しい問題に逢着するが, 経営論的にとらえ

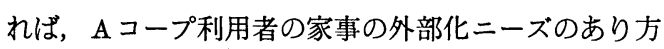
之, 農協側の開発する商品 (サービス) の機能および 価格とによって相互規定される側面をむつ. 本稿の目 的は，乙の後者のほうに光をあて，そてに含まれる経 済メカニズムを明らかにするととによって, 農協の生 活䞉買事業の今後のあり方について議論の素材を提供 することである1

丸山にならって, 主婦を家事サービスの供給者と擬 制すれば2)，主婦と農協を含むサービス産業は家計へ のサービス供給をめぐる競争主体とみなしうる. 経済 発展の過程で, 主婦の家事労働の機会費用が高まり， サービス産業の生産性が高まれば，乙の競争はサービ ス産業側に有利に働くであろう、けだしサービス産業 側の開発する新技術が規模の経済を追求するようなも のであれば，労働生産性格差を背景にサービス産業側 は圧倒的な勝利を収めるであろう.

しかし，一方で女性の生き方・考え方は生活必需品 の充足の過程を経て個性化・多様化が著しく、家事サ 一ビスの購入は主婦の家事に対する動機・態度・期待 など消費者心理のあり方によって左右されることが多 いといわれている.こうした心理学的消費者行動理論 の重要性の高まりを背景として, マーケティング・広 告の研究分野では, 年齢・学歷・職業・収入などによ る古典的セグメンテーションによるマーケティングか
ら，生活意識・生活様式などによる新しいセグメンテ ーションによるマーケティングへと, その研究の方向 が変化している3゙．本稿においてす，家事の「役割意 識」「楽しみ意識」という 2 つ生活意識にもとづい て主婦をセグメントし，そのセグメント間にある家事 の外部化ニーズの強弱を明らかにするととあに，乙れ ら 2 つの生活意識がどのような社会的・経済的環境と 生活様式のなかから生まれてくるかを明らかにするて とによって，サービス産業側がターゲットとすべき主 婦像を描き出そうとする.

「個の時代」といわれるなかにあって，乙の種のマ 一ケットセグメンテーションは, メーカーおよび小売 業にとって不可欠なあのとなりつつあり，PO S シス テムを使った顧客別商品データベースにより, 顧客の ニーズを科学的に予測する手法を開発していくのが時 代の潮流になっている. 今回われわれのとったセグメ

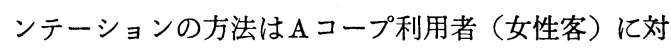
するアンケート調査であるが, 将来は顧客別商品デー タベースとアンケート調查をリンクさせるととによ り，セグメントでとにあっとも適したサービス・商品 の製品化之販売促進策を考えていくのが農協にとって あ必要になってくるであろう4).

\section{2. 分析のフレームワークとアンケート 調査の内容}

\section{（1）家事をめぐる主婦とサービス産業の競争}

経済発展のプロセスは, 新技術の開発を通して, ば らばらの，そしてすき間の多い暮らしのための活動 （労働・家事労働・余层）の時間配分を，まとまった， そしてすき間のない時間配分に変えていく合理化のプ ロセスであるから，それに応じててれら活動について は時間が最大の制約要素となって, あらゆる活動を時 間節約的なすのに変えていくと考えることができる. 家事の外部化むしくはサービス経済化とは, 自分が家 事をやって放棄せざるをえない仕事による収入より あ，他人にその家事をやってもらって支払う代金のほ 
図 1 家計内生産と家計外生産の選択モデル

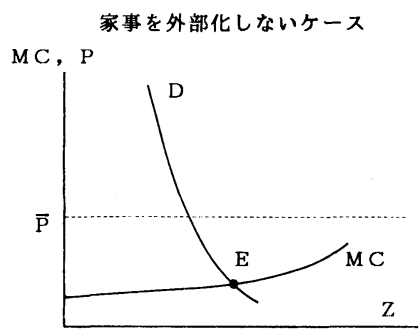

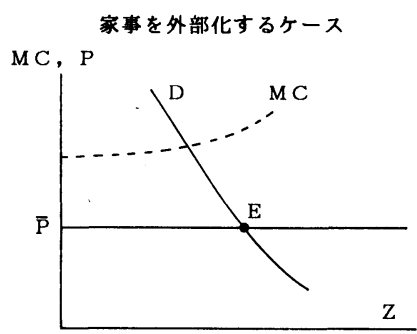

うがはるかに小さいという打算によって支えられてい る新しい経済活動のうねりである．なぜ幼児の面倒を 夫がみず妻がみるか，なぜ幼児の面倒を妻がみず姑が みるか，なぜ幼児の面倒を家族がみず保育所比預ける か，てれらすべては以上の経済的打算の上に成り立っ ている.

ただし，乙の経済的打算はいわば真空状態における 羽毛の落下実験に似て, 空気中の気体にあたるさまざ まな抵抗要素の存在を捨象している，稲作における作 業受委託や経営受委託が進展しないように，主婦の家 事サービスにおいてあ, そこに倫理感なり価值感が, あるいは過去の経験や投資の経緯が働いて，その外部 化を阻止している可能性は大きい，とくに主婦は家族 ・社会に対する「配慮の世界」に生きており，その生 活体系は外的要因によって大きく左右される側面も否 定しがたい.

時間配分の理論，むしくは家計内生産家計外生産 かの選択理論は, ベッカー, 井原, 田中, 丸山らによ って提示されてきたが5)，乙てで想定するモデルはマ 一ケットセグメンテーションという目的にそくしてそ れらをより単純化したものである.

家計は家族全員の選好の結果として，ある1つの有 益な便益 (commodity，例えば夕食）に対し何らかの 值踏みを行なうが，その行為を需要関数として表わす とすれば，その供給側の行為（夕食材料を購入し，調 理し，後かたずけをする）供給関数で表わせれるは ずである．そして，その供給側の主体を主婦とすれ ば，その主婦は自らが生産した便益を家族に提供する 家計内生産の方法と, 外部のサービス産業から購入し た便益を家族に提供する家計外生産（その典型は出前 物）の方法との間でどちらをとるかという選択の局面 を迎える. 当然その主婦は費用の安いほうをとると想 定するのが妥当であろう.

サービス産業の提示するその便益の価格を $\bar{P}$ (一定) とすれば，それ之同質の便益を主婦が生産する場合の
短期総費用は次のように表わせれる.

$$
C=v X+r \bar{K}+w T
$$

ここで，Xは原材料の投入量を表わすべクトル， $\bar{K} は$ 設置されている一定の資本設備, $T$ は便益生産に要す る家事労働時間である.また, $v$ は Xの価格ベクトル， $r$ は単位資本費, $w$ は時間の価格である. いま, 便益 生産量をZで表わし, 家計内生産の投入関数として

$$
\left\{\begin{array}{l}
X=a Z \quad \text { ただし } a \text { はの投入係数ベクトル } \\
T=T(Z, \bar{K}) \text { ただし } T^{\prime}>0, T^{\prime \prime}>0
\end{array}\right.
$$

を想定すれば6)，その限界費用は次のようになる. $M C=v a+w T^{\prime}$

図 1 亿示すように，MCが $\bar{P}$ をめ゙ってそれより上 に位置したり，下に位置したりするのは，それぞれの 主婦についてその置かれた社会的・経済的環境, 過去 の経験，投資の経緯などの違いから，MCの 構成要素 である $a, w ， T^{\prime}$ の大きさが異なるからである. その なかでもとくに大きな差をあつと考えられるのが，時 間の価格 $w$ 之家事労働の限界投入量 $T^{\prime}$ である.

wについては労働の限界貨金率を与えるというのが 代表的見解であるが，乙の措置は必ずしも妥当ではな い. その理由は, 家事労働之対外労働供給では労働条 件の面で相違があり，その条件の相違によって貨金率 之時間の価格に差が生じる可能性があるのみならず, 各主婦がその相違をどの程度の大きさに評価するかは その主婦の生活意識・生活様式のあり方によって左右 されるからである. とくに，家事労働は農業労働之同 様に待ち行列を作らず即座にそしていつであ従事でき る点に特色があり, 需要者側から指定労働時間等の制 約を受ける対外労働供給とは性格を異にしている. こ のことは，同一の貨金率・労働条件に直面している主 婦であってあ，やりがいや生きがいなど家事に対する 姿勢, すなわち「役割意識」と「楽しみ意識」のあり 方によって各主婦の想定する時間の価格に差が生じや すいととを示している。「役割意識」「楽しみ意識」の 高い主婦ほどwは低く，したがってそのような主婦 
は, サービス産業に対して強い競争力をあつと想定で きる.

$T^{\prime}$ についてあ「役割意識」「楽しみ意識」が大きな 影響を与えるが, とくにてれは過去の経験の多頞, 耐 久消費財設置の経緯など，生活様式のあり方と結びつ いて主婦間で差が生じやすい. とりわけ高い技能を必 要とする便益の生産においては, 過去に多くの経験を 積み，手際のよい家事を行なえる主婦や，多機能・高 機能の耐久消費財を所有している主婦など, その生活 様式全体が生産者としての高い能力を保証するような 体系をむつ主婦ほど低いT'をむつと考えられる．した がって，てのような主婦もまたサービス産業にとって 脅威である.

生活意識・生活様式の違いが家事の外部化に与える インパクトに, 供給面とならんで需要面からのルート がある. すなわち, 生活意識・生活様式のあり方が便 益消費者としての主婦の立場を通して需要関数の位置 を規定し，それ応じて家事を内部化したり外部化し たりするというルートである. 図1の「家事を部分的 に外部化するケース」から明らかなように, 需要関数 が左に位置する場合はその家事を外部化することはな いが，右へシフトしていく場合にはそれに応じて家事 を外部化する度合いは増えていくと予想できる. とく に教育・文化や趣味的・自己実現的活動など主婦の自 由裁量の余地の大きい便益については, 「役割意識」

「楽しみ意識」の高まりがその便益に対する高い値踏 みをもたらし，需要を増やすような㗢きをする．した がって，需要面からみるとこのような主婦はサービス 産業にとって優良顧客になりうるのである.

以上の理由から, 家事をめぐる主婦とサービス産業 との競争関係は, 優れた商品開発力と規模の経済を追 求した資本集約的技術のもとで達成されるサービス産 業側の $\bar{P}$ と、「役割意識」「楽しみ意識」という $2 つ の$ 生活意識のあり方, およびそれと密接な関係をあつ生 活様式のあり方によって規定される主婦側の $M C$, お よび家族全体があつその便益に対する值踏みの大きさ $D$ の相対的位置関係の問題に帰着できると考えられ る.

\section{(2) アンケート調査の設計}

上で述べた競争モデルを念頭に置きつつ,われわれ は家事を「晒常的買物」「炊事」「洗たく」「子供の教 育・しつけ」の 4 つに分類し, それぞれの家事につい て「役割意識」と「楽しみ意識」の高低》かから調查対 象者である主婦を次の 4 セグメントに分けていった.
役割意識が高い・楽しみ意識が高い

$\begin{array}{lll}\text { " 高い・ } & \text { " 低い } \\ \text { " } & \text { 低い. } & \text { 高い } \\ \text { " 低い. } & \text { " 低い }\end{array}$

次に，分類した 4 つの家事に関連するサービス二便 益として以下の 7 つのサービスを想定し，そのサービ スの利用状況・利用希望の多頞を質問し, セグメント ごとの関連サービスに対するニーズの強弱を求めてい った8).

日常的買物

夕食材料の配達サービス

通信肘売・カタログ販売

炊 事

出来上がりのそうざい

外食や出前物

洗たく

Y シャツ・ブラウスのクリーニング

子供の教育・しつけ

ピアノ・水泳教室などのけいて事教室

家庭教師や学習塾

そしてさらに，「役割意識」「楽しみ意識」がどのよ うな社会的・経済的環境亡生活様式のなかから生まれ てくるかをみるために，基本属性と生活様式に関する いくつかの質問を行ない早， セグメントでとの特徵を 求めていった，基本属性に関する質問は，本人の年龄・ 職業・定住度, 夫の職業, 家族員数, 末子年龄, 家計所 得, 持ち家の有無などから成り立ち, 生活様式に関す る質問は, 家計簿の記帳有無, 家具・インテリアなど を变えての雾囲気づくりへの志向, 宣伝中の新製品に 対する購買志向, 女性雑誌加らの情報収集の有無, サ ークル活動参加の有無, 家族旅行の有無, 自分専用の自 動車所有の有無, ローン・クレジット利用の有無, 男女 差のある教育に対する賛否などから成り立っている.

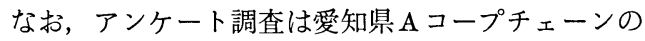
メンバー店のなかから，都市的・中間的・農村的立地 をそれぞれ代表すると思われる店を 1 店ずつ計 3 店選 び，各店 800 枚ずつを月曜日に店頭配布（時間に偏り が発生しないように配布）し，後日に店頭回収した. この意味で回答者はその店の固定客とみなせる．回答 数は1538で, 回収率は $64.1 \%$ であった。

\section{3. アンケート調査の結果とその考察}

（I）家事別にみた主婦の役割意識と楽しみ意識

表 1 は,「日常的買物」「炊事」「洗たく」「子供の教 


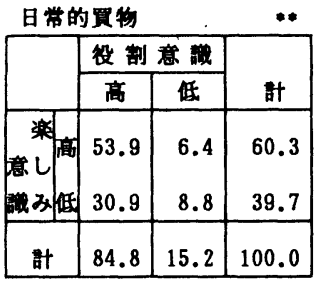
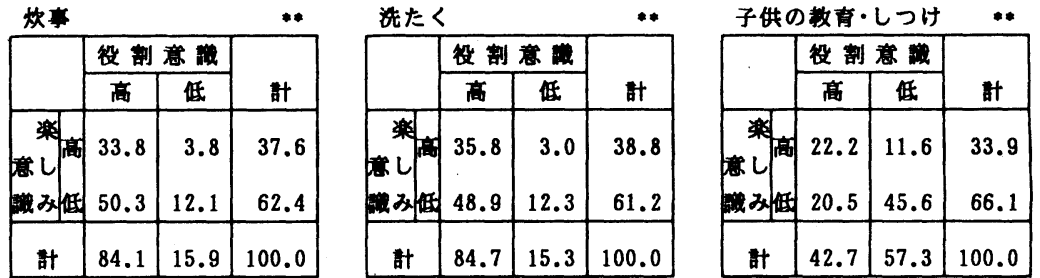

注）1. **はカ1 2 乗検定において有意水準 $1 \%$ で有意.

2. 調查対象者の「役割意識」「楽しみ意識」の高低への分割は本文注 7 参照.

育・しつけ」の $4 つ の$ 家事について, 役割意識と楽し み意識の高低から調査対象者を 4 セグメントに分け, その構成比を求めたあのである. この表で注目すべき 点は次の 4 つである.

第 1 は，いずれの家事についても，「役割意識」「楽 しみ意識」間の独立性検定（ $\chi^{2}$ 検定）において $1 \%$ 水 準で有意である（独立でない）之判定されているとと である．てのととは，「役割意識」と「楽しみ意識」 が似た概念であることを示している.

第 2 は，「役割意識」だけについてみると,日常的買 物, 炊事, 洗たくの場合は役割意識の高い主婦が全体 の84 85\%にのぼるのに対して，子供の教育・しつけ の場合はそれが42.7\%に低下することである.これは 家庭の主婦にとって自分の役割之考える家事の範囲が 買物, 炊事, 洗たくに限られ, 子供の教育・しつけは 除外されやすいことを示している.

第 3 は, 「楽しみ意識」だけについてみると, 日常 的買物では楽しみ意識の高い主婦が全体の $60.3 \%$ であ るのに対して，そのほかの家事ではそれが34〜39\%に 低下することである．乙のことから，日常的買物は主 婦にとって一種の知楽性をむつ家事であるといえる.

第 4 は，それぞれの家事で最頻值（モード）をとる セグメントが異なり, 日常的買物では役割意識と楽し み意識の（高い, 高い) セグメントが, 炊事と洗たく では（高い，低い）セグメントが, 子供の教育・しつ けでは（低い，低い）セグメントがそれぞれモードを とるととである.

これらのととから, 前節のフレームワークにそくし ていえば，主婦の日常的買物コストはかなり安く見積 あられている可能性があり，てのためサービス産業側 の提供する各種買物サービスは「買物の仕事と楽しみ を奪うあの」とみなされやすく，そのサービス利用に あたってはかなり抵抗が強いものと予想される，一般 にはホームショッピングの時代が間近であるとの認識
が強いが，乙れは主婦の生活意識とはかけ離れた企業 側の経営技術革新の側面だけを強調した物の見方とい えるだろう. これに対して, 欣事, 洗たく，子供の教 育・しつけに対する主婦の負担感は重く，一方で機能 ・価格比（コストパフォーマンス）の優れた耐久消費 財を購入するてとによってコスト低減がはかられ，他 方で外部サービスを購入することによって家事労働の 軽減がはかられていると理解できる.

（2）役割意識・楽しみ意識によるマーケットセグメ ンテーションの有効性

表 2 は, 表 1 で分割した各セグメントについて関連 サービスの利用率と利用希望率（正確には利用者比率 之利用希望者比率）を求めたあのである. この表で, 実線で囲まれているセグメントは欄外に示される回答 者全体の利用率 (平均利用率) 上り屯高い利用率をむ つセグメントであり，家事をよく外部化するセグメン 卜と考えられる．反対に破線で囲まれているセグメン 卜は平均利用率よりあ低い利用率をむつセグメントで あり，家事をあまり外部化しないセグメントと考えら れる．実線で囲まれるセグメントと破線で囲まれるセ グメントとの利用率のギャップが大きいほど，そのマ 一ケットセグメンテーションは有効であることを示 し，その有効性は表 1 之同様に $\chi^{2}$ 検定によって確めら れる. * は $5 \%$ 水準で，また**は $1 \%$ 水準で有意で ある.

したがって，乙の表から指摘できる第 1 の点は, 「夕 食材料の配達サービス」「Yシャッ・ブラウスのクリ 一ニング」については利用率・利用希望率ともにセグ メント間に有意な差違が認められず，乙てでのセグメ ンテーションが必ずし屯成功しているとはいえないと とである.

第 2 に指摘すべき点は, 「出来上がりのそうざい」 と「学習塾」において典型的に対比できるように,「役 割意識」「楽しみ意識」の高いセグメントは炊事関連 
表 2 各セグメントの家事サービス利用率と利用希望率

(単位 :\%)

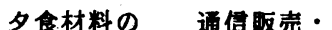

配達サービス カタログ服売 そうさい 出前物 クリーニングけいこ事教室 学習

\begin{tabular}{|c|c|c|c|c|c|c|c|c|c|c|c|c|c|}
\hline \multicolumn{2}{|c|}{7.7} & \multicolumn{2}{|c|}{24.9} & \multicolumn{2}{|c|}{56.9} & \multicolumn{2}{|c|}{58.8} & \multicolumn{2}{|c|}{59.9} & \multicolumn{2}{|c|}{31.0} & \multicolumn{2}{|c|}{21.9} \\
\hline 7.6 & 9.2 & 25.3 & 34.7 & 50.2 & 60.3 & 57.7 & 60.3 & 60.3 & 54.4 & 38.3 & 42.5 & 27.2 & 22.9 \\
\hline 6.3 & 11.8 & 21.7 & 26.5 & 60.6 & 59.1 & 60.1 & 56.5 & 61.0 & 55.6 & 30.8 & 24.6 & 30.2 & 15.2 \\
\hline
\end{tabular}

\begin{tabular}{|c|c|c|c|c|c|c|c|c|c|c|c|c|c|c|}
\hline 希利 & \multicolumn{2}{|c|}{20.9} & \multicolumn{2}{|c|}{32.1} & \multicolumn{2}{|c|}{53.6} & \multicolumn{2}{|c|}{61.6} & \multicolumn{2}{|c|}{56.7} & \multicolumn{2}{|c|}{49.6} & \multicolumn{2}{|c|}{35.4} \\
\hline 用 & 20.5 & 27.6 & 32.0 & 41.8 & 45.6 & 58.6 & 56.7 & 53.5 & 53.2 & 52.2 & 50.9 & 69.3 & 38.6 & 41.9 \\
\hline 事 & 19.6 & 23.5 & 30.3 & 32.4 & 57.9 & 57.0 & 66.2 & 58.6 & 59.7 & 56.1 & 47.3 & 45.0 & 41.0 & 29.8 \\
\hline
\end{tabular}

注）1. セグメントの位置は表 1 と同じ.

2. カイ 2 乗検定において*は有意水準 $5 \%, * *$ は有意水準 $1 \%$ で有意.

3. 上段の利用率は「利用者」の当該セグメントにおける構成比を表わす. 下段の利用希望率は「利用希望者」の当該セグメン 卜における構成比を表わす。「利用者」「利用希望者」の定義は本文注 8 参照.

4. 欄外の数值は,「利用者」あしくは「利用希望者」の全体の構成比を表わす. 本文ではこれを「平均利用率」・「平均利用 希望率」と呼んでいる.

5. 実線枠はその「平均利用率」・「平均利用希望率」より高いセグメント，破線枠はその「平均利用率」・「平均利用希望率」よ り低いセグメントを表わす.

サービスに対してはそのほかのセグメントよりも低い 利用率・利用希望率をむつのに対し，子供の教育・し つけの関連サービスに対してはそのほかのセグメント よりあ高い利用率・利用希望率をむつととである.

このととは, 同じ家事の外部化ではあってあ炊事と 子供の教育・しつけでは違ったメカニズムによってサ 一ビス利用の意思決定がなされていることを示す．炊 事については,「役割意識」と「楽しみ意識」が高く, したがって家計内生産コストが安く見積もられている ことが，そのままストレートにサービス利用率の低さ に結びついている，その関係は図 1 の「家事を外部化 しないケース」と「家事を外部化するケース」の対比 によって端的に示すととができる. これに対して，子 供の教育・しつけではそのような供給面の関係だけで なく, そこに需要面の関係肪加味されて, 家計内生産 コストが安くとも高い需要価格に支えられて外部サー ビスを利用するセグメントと，家計内生産コストが高 くとも低い需要価格に引きずられて外部サービスを利 用しないセグメントとが混在することである. その関 係は図 1 の「家事を部分的に外部化するケース」にお いて，右寄りの $M C$ 亡それ以上に右寄りの $D$, 左寄り の $M C$ とそれ以上に左寄りの $D$ によって表わすことが できる.

第 3 亿指摘すべき点は, 上で述べた第 2 の点に関連 して，利用希望率についてだけみると，「役 割 意識」 と「楽しみ意識」のともに高いセグメントは, 炊事関 連サービスばかりでなく, 日常的買物, 洗たくの関連
サービスにおいても同様に低い利用希望率をむち，乙 れらの家事においてはできれば家計内生産で賄おうと する供給者としての姿勢が読みとれることである．乙 れに対して，子供の教育・しつけの関連サービスに対 しては依然として高い利用希望率をあち，子供たちに より多くの学習機会を与えたいとする需要者としての 顔をより強く表わしている.

（3）役割意識・楽しみ意識の組成機構

では，以上の家事の役割意識，楽しみ意識はどのよ うな社会的・経済的環境亡, 生活様式・生活体系のな かから生まれてくるのであろうか. 次にごれを炊事」 「子供の教育・しつけ」の場合についてみることにし よう10).

表 3 および表 4 は, 基本属性, 生活様式, 家族内役 割分担の各設問ごとにセグメント間の独立性検定を行 ない，その検定で $5 \%$ あしは $1 \%$ 水準で有意であっ た設問の項目を記載したものである. 表 3 は「炊事」, 表 4 は「子供の教育・しつけ」についてである，明らか に，乙の両者では各セグメントの内容に違いがある.

まず,「炊事」についてみていくと，その「役割意 識」の高低は，その主婦が炊事を専属的に行なってい るかどうかによって定まってくる，すなわち，炊事を 手伝ってもらえるような年上むしくは年下の女性がい ない核家族世帯の場合，炊事は結局その主婦の仕事に なり，それに応じて役割意識も高まるが，炊事を手伝 ってもらえるような年上むしくは年下の女性がいる直 系家族世帯の場合，その役割分担の関係があいまいに 
表 3 炊事のセグメント別人物プロフィール

役割意識高 い

基本属性 35 64 歳。既婚者。家族 4 人。末子小学生以上。家事に専念。夫は団 体・会社の役貝。所得 400 万以上。准組
楽

ᄂ

み

意

識

高

い

楽

ᄂ

み

意

識

低

い 合員。自分の代からこの地に住む。持ち家 （ローンなし）あり。

生活様式 家計梅つける。インテリアなど をかえて雾用気作り楽しむ。新製品の取り 入れ早い。女性雑誌よく誌む。サークル活 動熱心。家族旅行よくする。自行専用の自 動車もたない。ローン利用しない。

役割分担 炊事手伝う年上の女性いない、 年下の女性いる。炊事自分がする。炊事手 伝ってもらいたくない。

基本風性 $25 \sim 39$ 歳。既婚者。家族 3 人。末子中学生以下。自分の仕事 (パート) もつ者、家事に尃念する者両方あり。夫は 自営業者・常用雇用者。所得 700 万以下。 非組合員。自分の代からこの地に住む。持 ち家（ローンつき）もしくは借家に住む。 生活様式 家計簿つけない。インテリアな どかえない。新製品の取り入れ遅い。女性 雑誌䛠まない。サークル活動不参加。家族 旅行よくする。自分専用の自動車もつ。口 ーン利用する。

役割分担 炊事手伝う年上の女性・年下の 女性いない。炊事自分がする。炊事手伝っ てもらいたい。
役割意識 低

基本属性 45 歳以上。既婚者多いが、末 婚・離別・死別者含む。家族 5 人以上。末 子高卒以上。自分の仕事（農業・自営業・ 常用雇用）をもつ。夫は農業者・自営業者。 所得40 0 万以下と、700万以上に分か れる。正組合員。先祖代々この地に住む。 狩ち家（ローンなし）あり。

生活様式 インテリアなどをかえて雾囲気 作り楽しむ。新製品の取り入れ早い。女性 雑誌よく誋む。その他はいずれもはっきり しない。

役割分担 炊事手伝う年上の女性・年下の 女性いる。炊事誰がするかはっきりしない。 炊事手伝ってもらいたい。

基本属性 29 瓷以下。既婚者・未婚者。 家蔟 5 人以上。自分の仕事（農業・常用雇 用）もつ。夫は農業者もしくは定職をもた ない者。所得 400 万以下。正組合員。漞 の代からこの地に住む。持ち家（ローンな し）に住む。

生活様式 家計籍・インテリア・新製品の 取り入れ・女性雑誌・サークル活動・家族 旅行・自分軎用の自動車の有然・ローンの 利用などいずれもはっきりしない。

役割但担 炊事手伝う年上の女性・年下の 女性いる。炊和ほかの家族がする。炊事手 伝ってもらいたい。

注）1. 分割された 4 つのセグメントと各設問のクロス集計表を作成し，そのカイ 2 乗検定において有意水準 $5 \%$ むしくは $1 \%$ で有 意であった設問の項目を記載.

2. 項目の記載にあたっては観測度数と期待度数の差に着目して作成.

なり，その家族への依存心が芽生える. 炊事をめぐっ て，「時間の価格」の安い家族員間で葛藤が生じ，ひ いてはそれが役割意織の低下をむたらすのである．核 家族世帯の典型は定住度の低い非農家世帯であり, 直 系家族世帯の典型は定住度の高い農家世帯である.

てれに対して「楽しみ意識」の高低は, 基本的にそ の主婦にとって裁量可能な所得と時間の多㙞によって
定まってくる．核所得 ${ }^{11}$ が高く家事に専念できるよう な所得之時間が確保されていたり，高齢化して時間の 処分が自由になってくると, 炊事の楽しみ意識が高ま ってくる. と同時に, 生活様式屯高度化・多様化し, お金之時間を注ぎ込んだ消費指向的生活体系を編成す るようになる. 反対に, 世帯核が若龄でその所得が低 いと, それに応じてパート就業や農業就業, 育児など 
表 4 子供の教育・しつけのセグメント別人物プロフィール

役割意識高 い

基本属性 $30 \sim 44$ 歳。既婚者。家族 3 〜 人。末子幼児から高卒以上まですべて 在宅。家事に専念。夫は団体・会社の役員。 所得 700 万以上。本人この地に住んで10 年以上。 生活様式 家計籍つける。インテリアなど

注）表 3 と同じ. る。手伝ってもらいたくない。

基本属性 $30 \sim 54$ 歳。既婚者。家族 5 人以上。末子保育所 - 幼稚園以上。自分の 仕事（団体・会社の役員・パート）もつ。 夫は団体・会社の役員。所得 $400 \sim 70$ 0 万。本人この地に住んで $10 \sim 19$ 年。 生活様式 家計䈱つけない。インテリアな どかえない。新製品の取り入れ幄い。女性 雑誌䛃まない。サークル活動不参加。家族 旅行しない。自分専用の自動車もつ。ロー ン利用しない。男女差のある教育に賛成。 役割分担 子件の教育・しつけ手伝う年上 の女性いる。子供の教育・しつけ自分がす る。手伝ってもらいたくない。
役割意識 低 基本属性 25 4 歳。既婚者。家族 3 〜 人。末子小学校在学中まで。自分の仕 事（自営業・常用雇用）もつ。夫は自営業 者・常用雇用者。所得 $400 \sim 700$ 万。 本人この地に住んで 10 年末洏。

生活様式 家計簿つける。インテリアなど をかえて雾囲気作り楽しむ。新製品の取り 入れ遅い。女性雑誌呓まない。サークル活 動熱心。家族旅行よくする。自分専用の自 動車もつ。ローン利用しない。男女差のあ る教育に反対。

役劃分担 子供の教育・しつけ手伝う年上 の女性いない。子供の教育・しつけ誰がす るかはっきりしない。手伝ってもらいたい。
基本属性 24 歳以下または 45 歳以上。 末婚・離别・死別者。家族 1 人。末子在宅 の子がいない。自分の仕事 (常用雇用・パ 一ト）もつ。所得400万以下。本人この 地に住んで 20 年以上。

生活様式 家計簿・インテリア・新製品の 取り入れ・女性雑誌・サークル活動・家族 旅行・自分専用の自動車の有無・ローンの 利用・男女差のある教育などいづれもはっ きりしない。

役割分担 子供の教育・しつけ手伝う年上 の女性いない。子供の教育・しつけ誰がす るかはっきりしない。手伝いの希望はっき りしない。
で多くの時間がさかれ，同時に勤労者世带では住宅・ 自動車ローンに追われて金銭的に苦しくなり，炊事の 楽しみ意識が低下してくる，そして，乙の所得・時間 プレッシャ一は生活体系全体を労働指向的に編成さ せ，生活様式の高度化・多様化を妨げる要因となる。

次に「子供の教育・しつけ」についてみると，その 「役割意識」の高低は，炊事の場合之異なり，家族内 役割分担の関係が夫婦間で成立することにより，その
主婦がこれに対する夫の参加を不可欠と考えるか否か が差を生みだす. 夫の参加を要請し，同時に夫がその 要請に応じるような家庭の主婦ほど役割意識は低い。 このような家庭では概して子供は小さく，またその主 婦屯「男女差のある教育に反対する」など自分自身の 生活意見を強くもっている．他方，主婦の役割意識が 高まるのは夫の非協力により，もしくは子供の成長に よって，上で述べた夫婦間の意思疎通よりも親子間の 
意思眯通が重視されるようになってからであり，ての 場合は教育感についてあ「男女差のある教育に賛成す る」との伝統的価值意識をあつに至る.

てれに対して「楽しみ意識」の高低は，基本的に家 族数之所得の関係，すなわち 1 人 1 人の子供にかける ことのできる教育費の多萓によって定まってくる．核 所得が高かったり，あるいは核所得が低くとあ子供の 数が少なかったりすれば，1人あたりの教育費を高め るてとができ，それに応じて楽しみ意識屯高まってく る. と同時に，生活様式も高度化・多様化しはじめる が，とりわけ核所得が高い場合はその傾向が著しい. 他方，核所得が低くかつ子供数が多ければ，高い教育 費を捻出するためにパート就業し，そのほかの時間的 ・金銭的出費屯抑えるなど，その生活体系全体が労働 指向的に編成されるようになり，それに応じて楽しみ 意識む低下するようになる.

以上述べてきたように，「欣事」と「子供の教育・ しつけ」では「役割意識」「楽しみ意識」の組成機構 は異なるが，それにあかかわらずその基本は同一であ る. すなわち，「役割意識」は家計内分業・協働体制 のあり方によって，また「楽しみ意識」は主婦の裁量 可能な時間と所得の多寡によって規定されている.

\section{4. むすび}

多様化・個性化した組合員のニーズを本質的には同 一なものとみなし，それを集約することによって経済 団体としての存立基盤を見いだそうとするこれまでの 農協の事業方式からすれば，本稿で試みたようなマー ケットセグメンテーションの手法は農協にとってなじ みにくいものかむしれない。しかし，現実の事業を進 めていく上では，店舗利用者（必ずしも組合員だけで はない）之店舗経営の距離はむっと縮めていかなくて はならないことも事実である．とりわけ，日常的に地

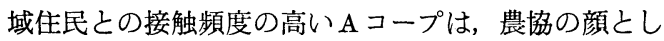
ての側面をもち，そてでの事業のあり方が地域におい て存在感のある農協になるかどうかの決め手ともなり うる. 他業態との競合激化が不可避な現在， 5 年先 ・ 10年先を見つめたマーケティングの手法開発は急務で ある.

一方，混住化社会における消費生活の高度化・サー ビス化は，地域住民の生活意識および生活様式の高度 化・多様化の所産であある. 生活体系をよく知らない 隣人に合わせるのではなく，自らの価値感・生活感に 合わせたかたちで商品・サービスを購入するという彼
らの姿勢は今後一層強まりとそすれ，弱まるとは考え にくい.

本稿によって明らかにされた生活意識の組成機構に よれば，主婦の家事に対する姿勢は，一方で家族構造 の变容により，他方で核所得と主婦に対して開かれた 労働市場のあり方の変化によって，相互関連的に変化 していくであろう.．この関連でわれわれがあっと屯重 視するのは主婦に対する賃金率と労働条件の今後の展 開についてである．乙の点についていえば，有職主婦 は, 今後, 所得税・健康保険料・年金負担の観点加ら 被扶養配偶者扱いを受ける年収の低い，すなわち労働 時間の短いパートタイマーと，その扱いを受けない年 収の高い，すなわち労働時間の長いフルタイマーに二 極分化すると予想されている12). むしてれが妥当であ れば，一方で就業の容易さから専業主婦がパートタイ マーに転化することによって，核所得む高く，しかす 裁量可能な時間之所得を充分にもった家事の「楽しみ 意識」の高い主婦が大量に創出され，他方で自動車・ 住宅ローンや，教育費を賄う必要からこの基準年収に 不満をむつパートタイマーの一部がフルタイマーに転 化するととによって，核所得が低く，しかむ裁量可能 な時間と所得を充分にもたない家事の「楽しみ意識」 の低い主婦が先鋭化されたかたちで創出されると予想 できる。

前節の分析結果によれば，乙の二極分化された主婦 たちの商品・サービスに対するニーズのあり方は明ら かに異なっており，例えば炊事についていえば，前者 は加工度が高く，しかも高級で高価な「調理素材」に 強いニーズをむち，後者は家計内生産であ容易に代替 できるような，低級で安価な「出来上がりのそうざ い」と「外食」に強いニーズをむっている．乙の両方 の需要量を正確に計量し，それに見合った商品とサー ビスを供給していくこと，および彼女らの生活ニーズ に合った商品とサービスを開発し，その開発した商品 ・サービスによって彼女らの潜在ニーズを掘り起こし ていくこと，乙れがてれからの農協マーケティングの 基本であるととはいうまであない.

注 1）農協の生活購買事業の経営問題, 組織問題を包 括した研究として, 石田正昭『サービス経済化の 進展之農協の生活購買事業』, 愛知県農業協同組 合中央会，1985，がある，本稿は，そこで行なわ れたアンケート調查をべースとして，Aコープ利 用者の家事の外部化要因について理諭的・実証的 検討を加えたものである。 
2）ただし，本稿では主婦による家事サービスの供 給が企業化し，サービス産業に転化する可能性は 排除している。丸山義酷『企業・家計複合体の理 論』, 創文社, 1984, 148〜152頁.

3 ）わが国におけるマーケットセグメンテーション の研究動向については, 飽戸弘『消費文化論』, 中央経済社, $1985,3 \sim 38$ 頁. また, 動機・態度・ 、期待など心理学的立場からの消費者行動理論に ついては, 斎藤精一郎「消費者行動の心理学」,

『経济学大辞典』I, 東洋経済新報社, 1980, 286 〜295頁.

4 ）筆者の管見では, 協同組合セクターでとの種の マーケティングに早くから着手しているのが灌神 戸生協である。

5) G.S. Becker, "A Theory of the Allocation of Time", The Economic Journal, Vol. 75, No 299，(1965. 9). 井原哲夫『商品と消費者の経済 学』, 日本経済新聞社，1978，41 69頁. 田中修 「労働供給と家事労働」『神戸大学経済学研究』 年報30（1983）. 丸山義皓 (前掲書).

6 ）家事労㗢の投入関数 $T=T(Z, \bar{K})$ は, 家計内 生座関数 $Z=f(T, K)$ を，Kを一定としたまま $T$ について解いたあのである。また， $T^{\prime}$ は $T$ を $Z$ に ついて一回微分したもの，T"は二回微分したも のである.

7 ）役割意識の高低は，「その家事をするととが自 分の役割と考えますか」という設問に対する選択 肢「はい」「いいえ」「どちらともいえない」のな かで,「はい」と積極的に肯定した者だけを役割意 識の高い者とした。楽しみ意識の高低む同様で， この場合は「その家事をするととは楽しみが多い ですか」という設問を用意した。

8 ）関連サービスに対する利用状況は，「よく利用 する」「ときどき利用する」「利用しない」の選択
肢を用意し，そのなかで前 2 者のいずれかに回答 した場合を「利用者」とみなし，その利用者の当 該セグメントの構成比によってニーズの強弱を判 定している (表 2 参照). 利用希望の強弱も同様 で，ての場合は「よく利用したい」「ときどき利 用したい」「利用したくない」の選択肢のなかで 前 2 者のいずれかに回答した場合を「利用希望者」 とした。

9）アンケート調查の設計にあたり, 三井情報開発 KK「サービス経済化の進展と家族構造の変容』, 総合研究開発機構，1983，89～152頁を参考にし た.

10）ここでは紙幅の制約から「日常的買物」「洗た く」のケースを割愛した。とれらの各セグメント の人物プロフィールは「炊事」のそれとほほ同一 であり，したがって以下の分析結果をそのまま適 用できる。

11) 核所得とは家計の経済的中心者の所得をいう. ことでのその把握は, 家計所得の大小と主婦の就 業有無からの推量によっている。一般に, アンケ 一ト調査では所得把握があっとあ困難であるとい われている。

12）この見解は, 高山憲之「年金改正之今後の課 題」、経済研究』第36巻第 2 号 (1985.4) のと りわけ147頁による.

〔付記】本稿は全国農業協同組合中央会昭和 58 年度農 業協同組合研究奖励事業の成果の一部である。な お, この研究にあたり, 愛知県農業協同組合中央 会, 愛知経済連 ( $\mathrm{A} コ$ コプチーン本部), およ びメンバー店の方々から多大なで協力をいただい た。記して感謝の意を表します.

（筆者・三重大学農学部） 